\title{
Comparative Study of Single Phase Cascaded and Hybrid Multilevel Inverters using Modified APODPWM Method
}

\author{
Fadhil Abbas M. Al-Qrimli \\ Engineering College \\ University of Baghdad
}

\author{
Athir A. Mohammed \\ Engineering College \\ University of Baghdad
}

\begin{abstract}
In this paper, a high frequency switching method of cascaded H-bridge and hybrid multilevel inverter have been proposed for equal power sharing between cells of multilevel inverter and for reducing THD. This switching method has been applied to 9-level inverter fed by PV system operated at Maximum Power Point. Comparative study of the THD reduction in multilevel inverter system with and without switching pattern for cascaded and hybrid multilevel inverter has been carried out to check the effectiveness of the proposed method in reducing the THD and balancing power sharing among different inverter cells.
\end{abstract}

\section{Keywords}

Cascaded multilevel inverter, Hybrid multilevel inverter, Alternative phase opposite disposition PWM, Multicarrier PWM, Photovoltaic system, MPPT.

\section{INTRODUCTION}

Multilevel inverters have gained much attention in the field of medium voltage and high power applications due to their many advantages over a conventional two level inverter, such as low voltage stress on power semiconductor, low harmonic distortions, good electromagnetic compatibility, reduced switching losses and improved reliability on fault tolerance. There are three main types of multilevel inverters: Diode Clamped Inverter, Flying Capacitor Inverter, and Cascaded Hbridge Inverter [1]. The classical multilevel inverter topologies produce a considerable amount of switching losses due to handful number of switching devices as the number of output levels is increased. Therefore to overcome these drawbacks a multilevel inverter topology to reduce number of switching devices is opted. The number of switching devices, total harmonic distortion, number of output levels and number of sources are the governing factors in a multilevel inverter topology [2]. Many methods of pulse width modulation PWM techniques are used to control the inverter. Most widely used pulse width modulation techniques are Space Vector Modulation SVM and Multicarrier Pulse Width Modulation MCPWM. The main drawback of SVM is that the number of computation is very large even though the user selects the best switching sequences. Selection of switching states is one more difficult task to implement on practical basis. To overcome these demerits of SVM, MCPWM are developed. There are different classification of multi carrier pulse width modulations like Phase shifted multi carrier modulation and Level shifted multi carrier modulation this to be is divided to three method: In Phase disposition method, Alternative phase opposite disposition method, and Phase opposite disposition method [3]. In this switching method, active periods of different bridges is different, diverse powers are delivered by different CMI's bridges. A modification of this switching pattern is proposed for solving these unbalanced powers sharing.

\section{PV AND MPPT SIMULATION}

In photovoltaic systems, solar energy is converted into electrical energy by photovoltaic (PV) arrays. PV arrays are very popular since they are clean, inexhaustible and require little maintenance. Photovoltaic systems require interfacing power converters between the PV arrays and the load. Equivalent circuit models define the entire I-V curve of a cell, module, or array as a continuous function for a given set of operating conditions. Photovoltaic cell is a non-linear device and can be represented as a current source in parallel with diode as shown in the circuit in Figure 1. The diode prevents a reverse bias current from flowing into the panel from the energy storage devices during the night [4].

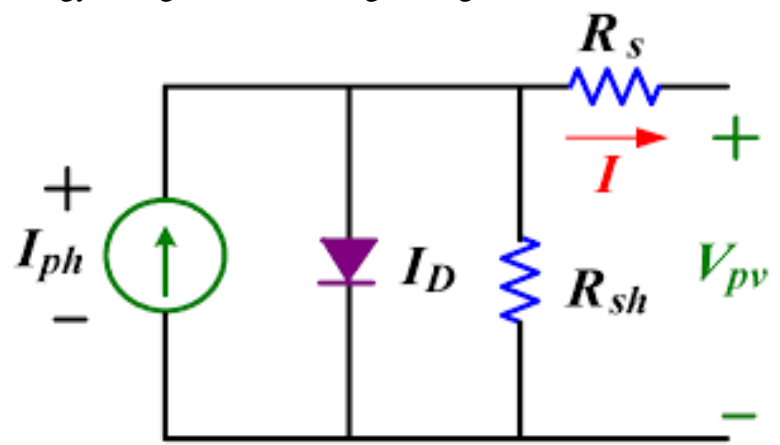

Fig 1: The electrical equivalent circuit of a PV cell [4]

The practical PV cell model includes the connection of series and parallel internal resistance, namely $R_{S}$ and $R_{P}$, The shunt value is very large and the series resistance is very small. These resistance values have little effect on the overall performance of the cells. which is expressed as the following equation [5].

$\mathrm{I}=\mathrm{I}_{\mathrm{PV}, \text { cell }}-\mathrm{I}_{\mathrm{o}}\left[\exp \left(\left(\mathrm{V}+\mathrm{R}_{\mathrm{s}} \mathrm{I}\right) / \mathrm{V}_{\mathrm{t}} \mathrm{a}\right)-1\right]$
$\mathrm{V}_{\mathrm{t}}=\mathrm{N}_{\mathrm{s}} \mathrm{k} T / \mathrm{q}$

Where, I, V, $\mathrm{V}_{\mathrm{t}}, \mathrm{q}, \mathrm{k}, \mathrm{T}, \mathrm{K}$ and a is the photovoltaic output current, photovoltaic output voltage, thermal voltage of array with Ns cells connected in series, electron charge (1.60217646 $\left.\mathrm{e}^{-19}{ }^{\circ} \mathrm{C}\right)$, Boltzmann constant $\left(1.3806503 \mathrm{e}^{-23} \mathrm{JK}^{-1}\right)$, temperature of the p-n junction in the unit of Kelvin, diode ideality constant, respectively.

The $\mathrm{I}_{\mathrm{PV} \text {,cell }}$ is the light generated current produced by a photovoltaic cell which has a linear relationship with the solar irradiance and temperature, as shown in the following equation: 
$\mathrm{I}_{\mathrm{PV}, \text { cell }}=\left(\mathrm{I}_{\mathrm{PV}, \mathrm{n}}+\mathrm{K}_{\mathrm{i}} \Delta \mathrm{T}\right) \mathrm{G} / \mathrm{G}_{\mathrm{n}}$

Where, $\mathrm{I}_{\mathrm{PV}, \mathrm{n}}$ is the light generated current at the nominal condition which are $25^{\circ} \mathrm{C}$ and $1000 \mathrm{w} \mathrm{m}^{-2}, \Delta \mathrm{T}=\mathrm{T}-\mathrm{T}_{\mathrm{n}}$ where $\mathrm{T}$ and $\mathrm{T}_{\mathrm{n}}$ is the actual and nominal temperature in unit Kelvin, $\mathrm{K}$ respectively. While $\mathrm{G}\left(\mathrm{wm}^{-2}\right)$ is the solar irradiation by the PV surface and $G_{n}$ is the nominal solar irradiation [5].

The diode saturation current, $I_{0}$ and its dependence on the temperature may be expressed by:

$\mathrm{I}_{\mathrm{o}=}\left[\left(\mathrm{I}_{\mathrm{sc}, \mathrm{n}}+\mathrm{K}_{\mathrm{i}} \Delta \mathrm{T}\right) / \exp \left(\left(\mathrm{V}_{\mathrm{oc}, \mathrm{n}}+\mathrm{Kv} \Delta \mathrm{T}\right) / \mathrm{aV}_{\mathrm{t}}\right)-1\right]$

Where $\mathrm{Kv}$ and $\mathrm{K}_{\mathrm{i}}$ is the open-circuit voltage/temperature coefficient and the short-circuit current/temperature coefficient. While $I_{s c, n}$ and $V_{o c, n}$ are the short-circuit current and open-circuit voltage under the nominal condition respectively [4].

Parameters of simulated PV module are listed in table 1.

Table 1: The parameters of a Clearline PV module for $1000 \mathrm{w} / \mathrm{m}^{2}$ and $25^{\circ} \mathrm{C}[6]$

\begin{tabular}{|c|c|}
\hline Model & Clearline PV \\
\hline Maximum Power $\left(\mathrm{P}_{\max }\right)$ & $330 \mathrm{~W}$ \\
\hline Current at Maximum Power $\left(\mathrm{I}_{\mathrm{mp}}\right)$ & $7.8 \mathrm{~A}$ \\
\hline Voltage at Maximum Power $\left(\mathrm{V}_{\mathrm{mp}}\right)$ & $42.5 \mathrm{~V}$ \\
\hline Open Circuit Voltage $\left(\mathrm{V}_{\mathrm{oc}}\right)$ & $53 \mathrm{~V}$ \\
\hline Short Circuit Current $\left(\mathrm{I}_{\mathrm{sc}}\right)$ & $8.4 \mathrm{~A}$ \\
\hline Number of cells $(\mathrm{N})$ & 84 \\
\hline Number of series cells $(\mathrm{Ns})$ & 3 \\
\hline Number of parallel cells $(\mathrm{Np})$ & 1 \\
\hline
\end{tabular}

The output power of PV array depends on temperature and solar irradiance; hence, the photovoltaic system should be able to track the operation point in order to obtain the maximum power. Due to its simplicity, perturb and observe $(\mathrm{P} \& \mathrm{O})$ method is implemented in this paper. This method is implemented via a boost converter. By applying a small perturbation in the terminal voltage, the output power is measured and according to the algorithm depicted in Figure 3, the boost converter is controlled.

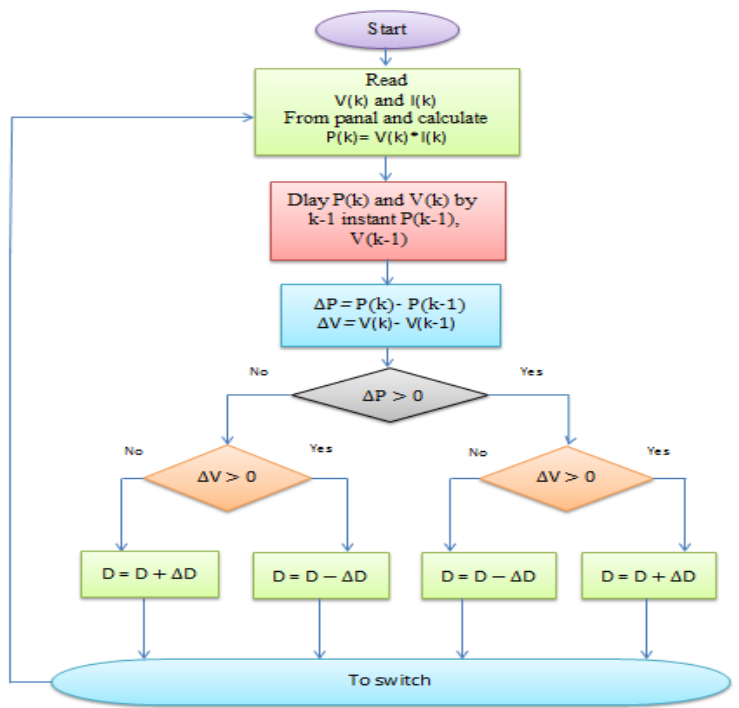

Figure 2: Flowchart of $\mathrm{P}$ and $\mathrm{O}$ MPPT algorithm

Fig. 3 shows the simulated PV and MPPT system in MATLAB/SIMULINK software.

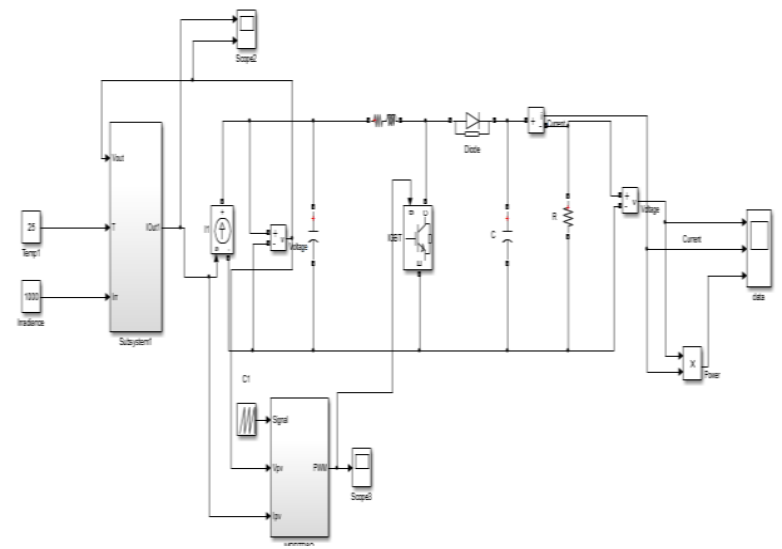

Fig 3: PV and MPPT SIMULINK model

The output voltage, current, and power of DC-DC boost converter for $1000 \mathrm{w} / \mathrm{m}^{2}$ and $25^{\circ} \mathrm{C}$ shown in Figure 4.

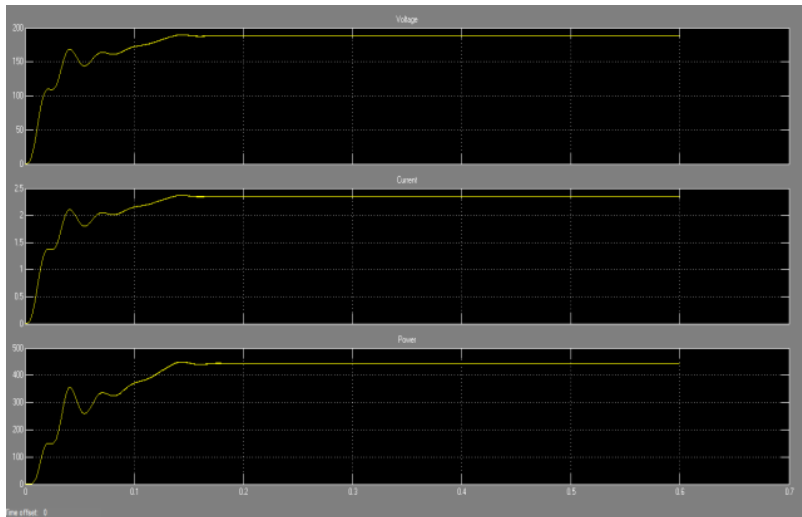

Fig 4: Output voltage, current, and power of DC-DC boost converter for $1000 \mathrm{w} / \mathrm{m}^{2}$ and $25^{\circ} \mathrm{C}$

\section{MULTILEVEL INVERTERS}

Different types of multilevel inverter topologies are presented in the literature Cascaded H-bridge, flying capacitors, and clamping diodes multilevel inverters. Cascaded H-bridge Multilevel Inverter CHMI has more advantages than other two mentioned that does not have flying capacitors and clamping diodes. The main drawback of CHMI is needing separate DC sources causing high cost and switching losses. To overcome the above disadvantages the choice is a hybrid multilevel inverter which is derived from cascaded $\mathrm{H}$-bridge inverter [7].

\subsection{Cascaded Multilevel Inverters}

An alternative multilevel inverter topology with less power devices requirement compared to previously mentioned topologies is known as cascaded $\mathrm{H}$-bridge multilevel inverter (CHB-MLI) and the topology is based on the series connection of H-bridges with separate DC sources. Since the output terminals of the H-bridges are connected in series, the DC sources must be isolated from each other. Owing to this property, CHB-MLIs have also been proposed to be used with fuel cells or photovoltaic arrays in order to achieve higher levels [8]. If $n$ is assumed as the number of modules connected in series, $m$ is the number of output levels in each phase as seen in according to (5).

$m=2 n+1$

The configuration of a 9-level cascaded inverter is depicted in Figure 5. This figure shows that increasing the number of level will be resulted by adding $\mathrm{H}$ - bridge inverters. 


\subsection{Hybrid Multilevel Inverters}

Proposed Hybrid Multilevel Inverter HMI is derived from conventional CHMI as shown in Figure 6. It consists of one main inverter and auxiliary inverters. These are cascaded to get the multilevel output. Main inverter consists of two switching devices cascaded to conventional $\mathrm{H}$-bridge inverter which consists of four switching devices. For $n$ level CHMI (n-1)/2 number of independent sources are required. In general independent sources may be renewable energy sources like same rated solar panels or fuel cells or wind energy sources [9].

\section{MODULATION TECHNIQUES OF MULTILEVEL INVERTERS}

The modulation methods used in multilevel inverters can be classified according to the switching frequency as shown bwelow.

\subsection{Classification of Modulation Strategies}

The main advantages of PWM inverters in comparison to square-wave inverters are (i) control over output voltage magnitude (ii) reduction in magnitudes of unwanted harmonic voltages (iii) improved power factor with unity displacement factor [10]. Modulation techniques that work with high switching frequencies have many commutations for the power semiconductors in a cycle of the fundamental output voltage. Multilevel inverters generate sinusoidal voltages from discrete voltage levels, and Pulse Width-Modulation (PWM) strategies accomplish this task of generating sinusoids of variable voltages and frequencies. Several techniques for the implementation of PWM for multilevel inverters have been developed [11].

\subsection{Multicarrier PWM Techniques}

Multilevel SPWM needs multiple carriers. Several multicarrier techniques have been developed to reduce distortion in multilevel inverters. Multicarrier PWM techniques entail the natural sampling of a single modulating or reference waveform typically being sinusoidal same as that of output frequency of the inversion system, through several carrier signals typically being triangular waveforms of higher frequencies of several kilo Hertz discussed by McGrath et al (2002) and Samir Kouro et al (2008). They can be categorized as follows Phase shifted multi carrier modulation and Level shifted multi carrier modulation this to be is divided to three method: In Phase disposition method, Alternative phase opposite disposition method, and Phase opposite disposition method [11].

\subsection{ALTERNATIVE PHASE DISPOSITION SPWM (IPDSPWM) SWITCHING METHOD}

Alternative Phase Opposite Disposition PWM (APODPWM) technique is used as illustrated in Figure 7 and Figure 8. As can be seen, carrier signals are compared to the reference Voltage at $50 \mathrm{~Hz}$ to decide between two different voltage levels, eight carriers (Number of levels-1) are arranged in vertical shifts with all the signals in phase with each other, called Alternative Phase Opposite Disposition PWM (APODPWM) to generate pulses for 9-level topology. Since each carrier is associated with two levels, the control signal has to be directed to the appropriate semiconductors in order to generate the corresponding levels.

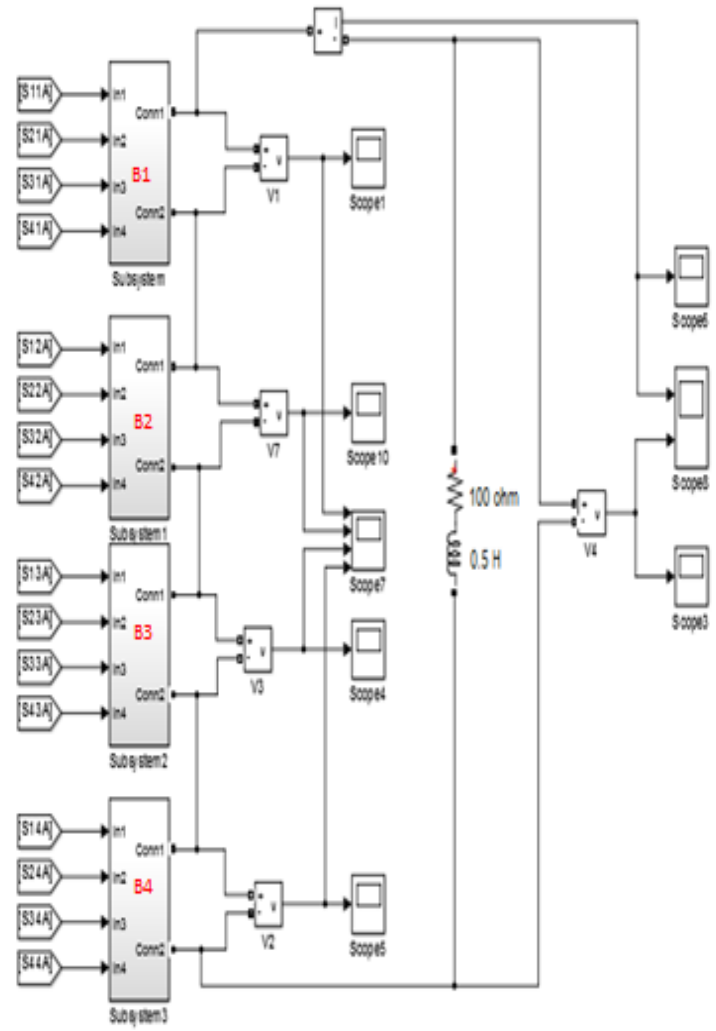

Fig 5: 9-level single phase cascaded multilevel inverter

The SIMULINK module of single cell for APODPWM ninelevel single phase CMLI shown in Figure 6, which is consists of four switching devices (IGBT's), four antiparallel diodes, and DC link capacitor, which is connected in parallel with PV array to reduce the dc ripple.

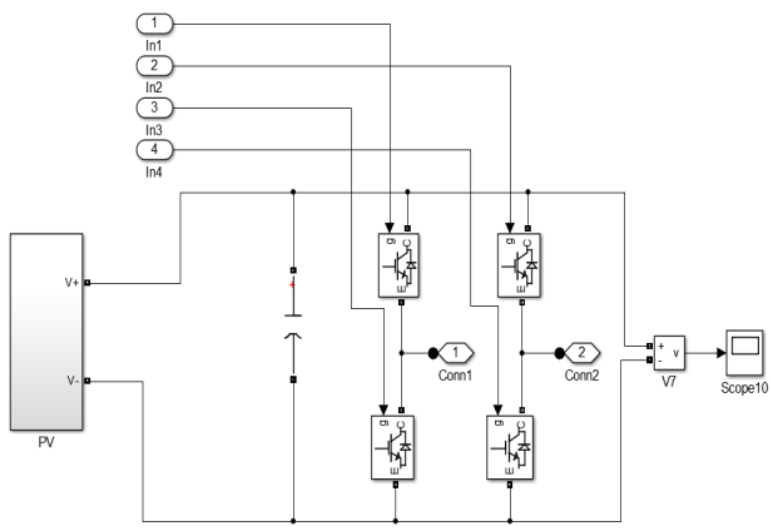

Fig 6: Simulink module of single cell for APODPWM nine-level single phase CMLI 


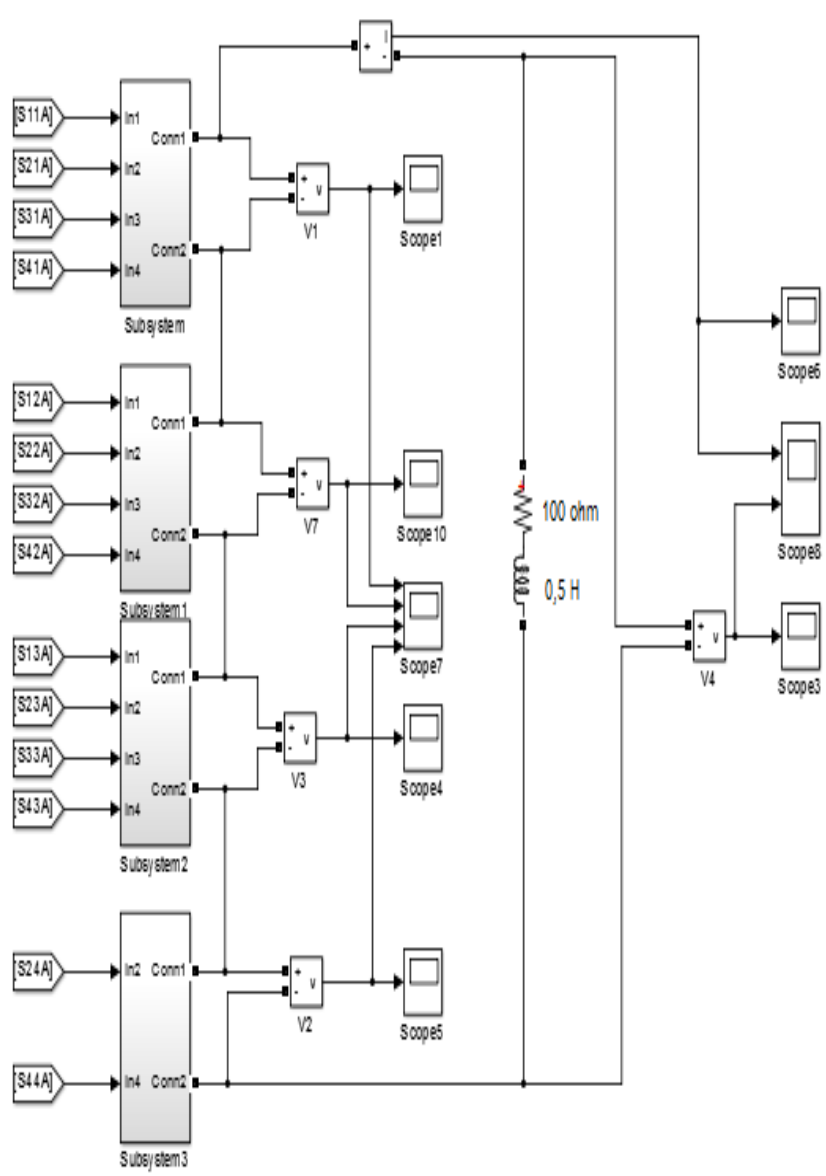

Fig 7: 9-level single phase hybrid multilevel inverter

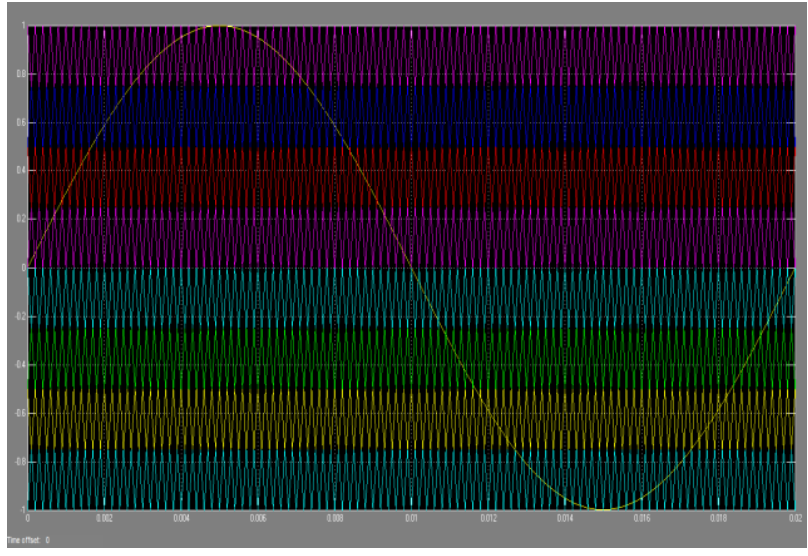

Fig 8: Comparison between the carrier waves and reference sinusoid wave for cascaded multilevel inverter

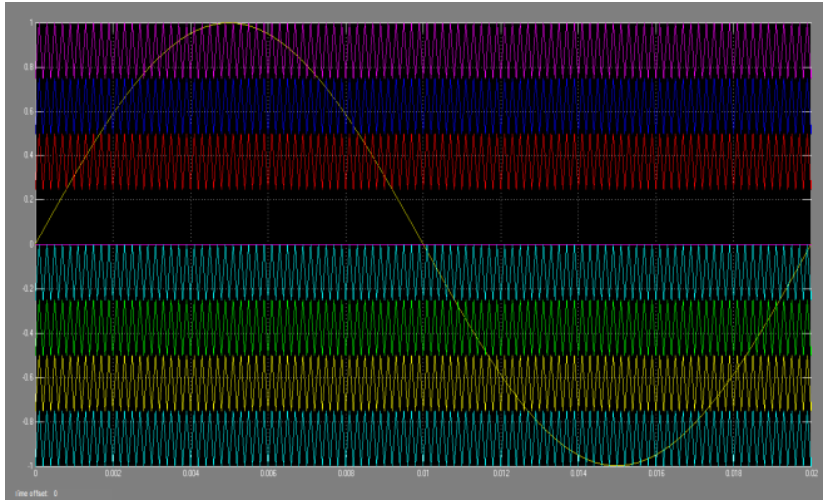

Fig 9: Comparison between the carrier waves and reference sinusoid wave for hybridd multilevel inverter

For THD comparison, in cascaded multilevel inverter and hybrid multilevel inverter are compared and harmonic content of these types are depicted in Figure 5 and Figure 7. As shown in Figure 10 and Figure 11 the THD of hybrid multilevel inverter is less than THD of cascaded multilevel inverter. These results are performed in 5kH switching frequency and 1 modulation index. By balancing the power delivered by different bridges in Alternative Phase Opposite Disposition PWM and without changing in output voltage of multilevel inverter, it will be a suitable switching method in power conditioning application. Figure 12 and Figure 13 show the output phase voltage of 9-level cascaded and hybrid multilevel inverter in Alternative Phase Opposite SPWM switching method respectively.

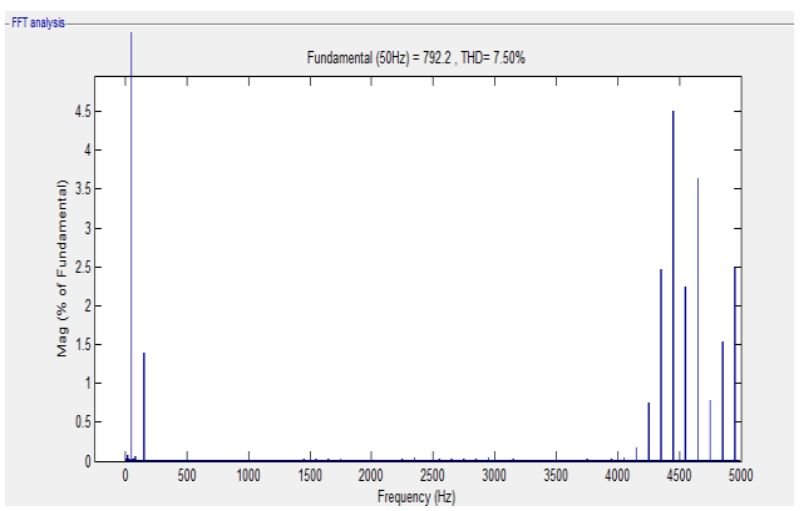

Fig 10: FFT analysis of cascaded multilevel inverter

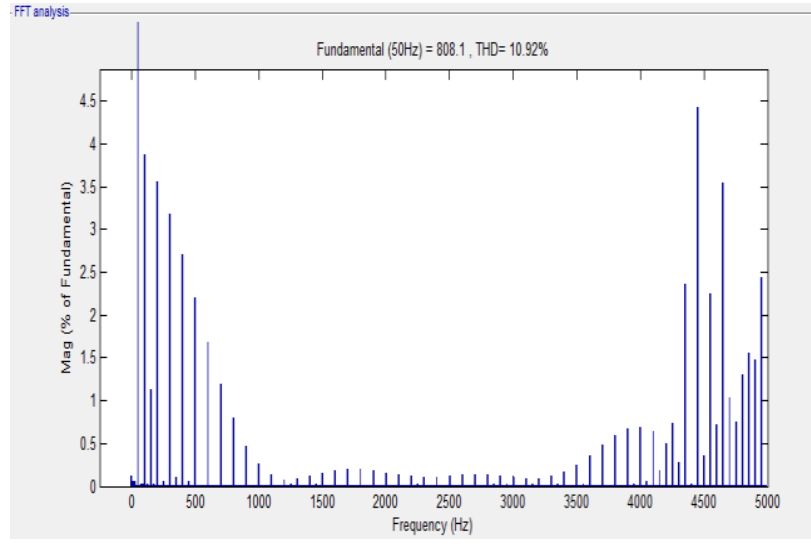

Fig 11: FFT analysis of hybrid multilevel inverter 


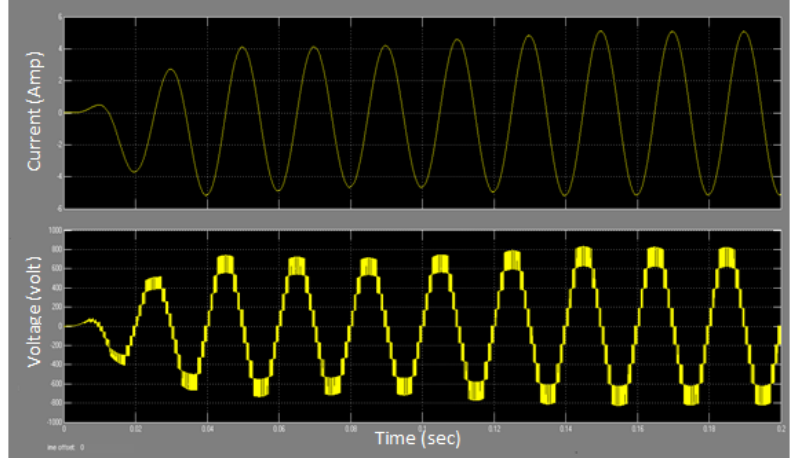

Fig 12: Output current and voltage of 9-level cascaded multilevel inverter in Alternative Phase Opposite SPWM switching method

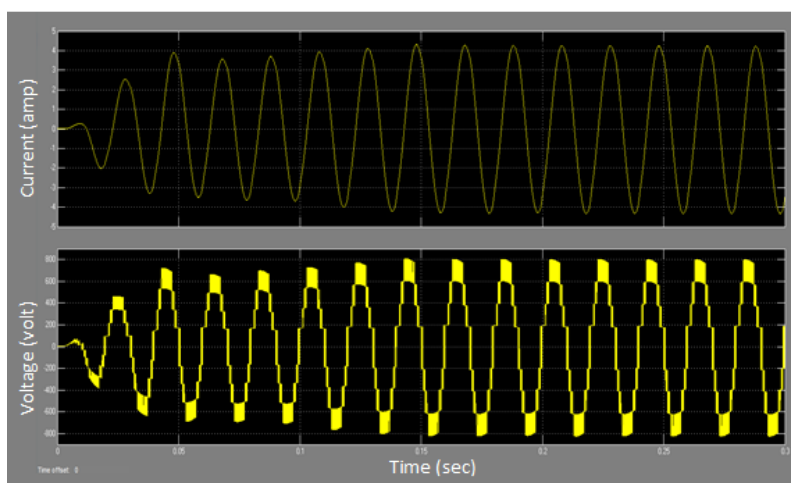

Fig 13: Output current and voltage of 9-level hybrid multilevel inverter in Alternative Phase Opposite SPWM switching method

\section{PROPOSED METHOD}

In the switching pattern which is proposed in this paper, the swapping of DC levels of different cells is taken place at each switching period (period of switching frequency). Since the average DC level of different cells are the same, equal power sharing between cells is obtained. These simulated carrier waves are shown in Figure 14 and Figure 15 for cascaded and hybrid, respectively considering the switching frequency equal to $5 \mathrm{kH}$.

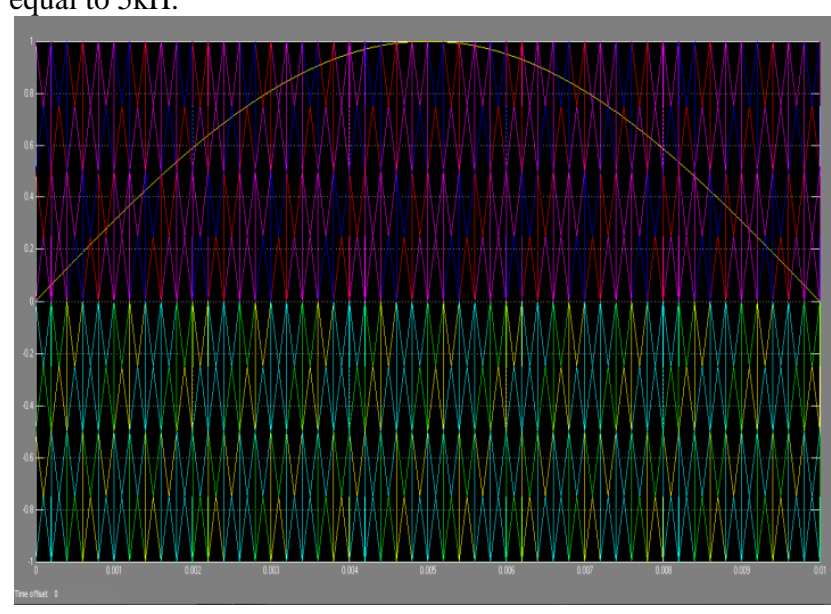

Fig 14: Carrier waves in proposed switching method considering $5 \mathrm{kH}$ switching frequency for cascaded multilevel inverter

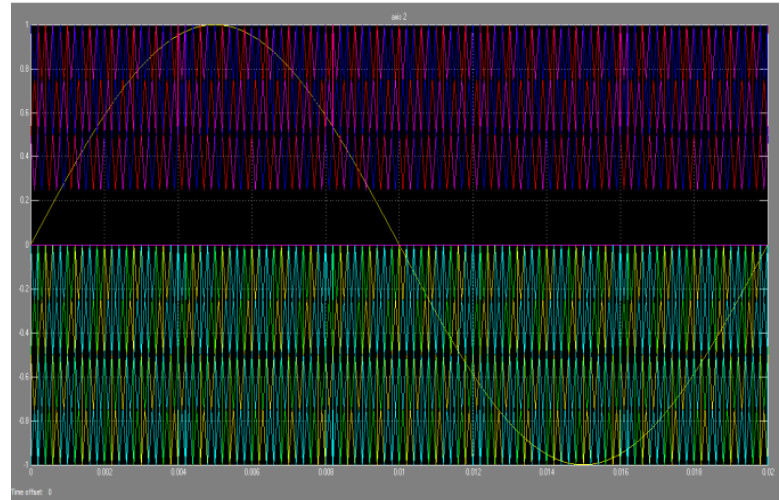

Fig 15: Carrier waves in proposed switching method considering $5 \mathrm{kH}$ switching frequency for hybrid multilevel inverter

\section{COMPARISON OF CASCADED AND HYBRID MULTILEVEL INVERTERS FOR PROPOSED METHOD}

In this section, the proposed switching method which is the modification of APODSPWM switching method is applied in 9-level cascaded and hybrid multilevel inverter. The amount of the impedance of AC load is considered as $100+\mathrm{j} 57 \Omega$. Simulation results show effectiveness of this method in sharing equal powers among different cells of the multilevel inverter which are supposed to be PV arrays; furthermore, results show that DC voltage ripples which cause inter harmonics are less than previous similar switching method; Hence for allowable DC voltage ripple, smaller capacitor is required.Table 1 show the voltage ripple of cascaded and hybrid multilevel inverters before and after proposed method. Figure 16 and Figure 17 show the output phase voltage of 9level cascaded and hybrid multilevel inverter by applying proposed switching method respectively.

Table 2. Analysis of Voltage ripple for different inverter (before and after swapping)

\begin{tabular}{|c|c|c|}
\hline & $\begin{array}{c}\text { Voltage ripple } \\
\text { before } \\
\text { swapping }\end{array}$ & $\begin{array}{c}\text { Voltage ripple } \\
\text { after swapping }\end{array}$ \\
\hline 9-level CMLI & $10.7 \%$ & $7.7 \%$ \\
\hline $\begin{array}{c}\text { 9-level } \\
\text { HMLI }\end{array}$ & $6.9 \%$ & $5 \%$ \\
\hline
\end{tabular}

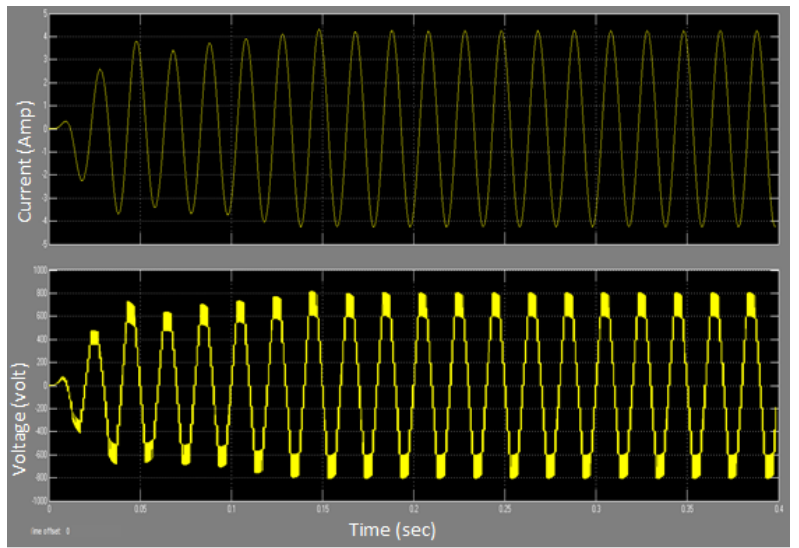

Fig 16: output current and voltage of 9-level cascaded multilevel inverter by applying proposed switching method respectively 


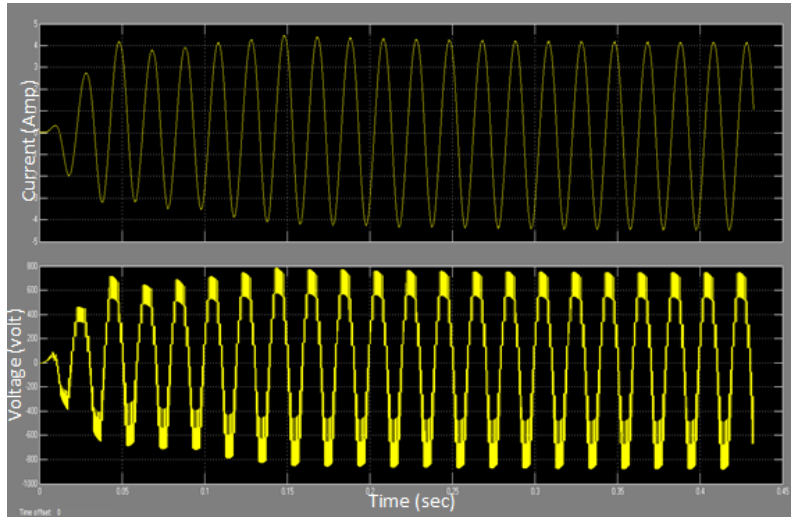

Fig 17: output current and voltage of 9-level hybrid multilevel inverter by applying proposed switching method respectively

\section{CONCLOSION}

In this paper harmonics content of APODPWM switching method that is used in multilevel inverters is proposed. The simulation results show that APODPWM have much better harmonics content for while this pattern is not suitable for power conditioning application due to unequal power sharing problem between different cells of CMI. A novel switching pattern which modifies the Alternative Phase Opposite Disposition is proposed in this paper. This method applied to 9-level cascaded and hybrid multilevel inverters fed by 4 photovoltaic arrays which are operated at their maximum power point. From Table 1 the voltage ripple of CMLI and HMLI after applying a modified method is better than using conventional APODPWM.

\section{REFERENCES}

[1] Pires, V. F., Martins, J. F., Foito, D., and Hao, C. 2012. A Grid Connected Photovoltaic System With A Multilevel Inverter And A Le-Blanc Transformer, International Journal of Renewable Energy Research, Vol. 2, No. 1.

[2] Krishna, M. D., and Vadhera, S. 2013. Comparative Study of Hybrid and Cascaded H-Bridge multilevel Inverters, International of Research in Engineering and Technology, Vol. 2, Issue 8, PP. 405-410.
[3] Gupta, S. R., and Anitha, G. S. 2015. PD-PWM Based Cascaded H-Bridge Multilevel Inverter for Photovoltaic Systems, International Journal of Advanced Research in Electrical, Electronics and Instrumentation Engineering, Vol.4, issue 7, PP. 6072-6078.

[4] Patel M. Z. and Maniar T. B. 2016.Design and Simulation of Boost Converter UsingP \& O Technique for PV System, International Journal of Science and Research (IJSR), Vol. 5, 2016.

[5] M.G. Villalva, J.R. Gazoli and E.R. Filho, "Comprehensive approach to modeling and simulation of photovoltaic arrays", IEEE Trans. Power Electron. pp.1198-1208, 2009.

[6] Datasheet of a Clearline PV module for $1000 \mathrm{w} / \mathrm{m} 2$ and $25^{\circ} \mathrm{C}$

[7] Athira, R., and Arun, S. 2013. Three Phase Multi_string Boost Front -End Hybrid Multilevel Inverter for Standalone system, International Conference on Advanced Computing and Communication Systems ICACCS.

[8] Raj, K. B., Meenakshi, J., and Sreedevi, V. T. 2014 Power Quality Analysis of A PV Fed Seven Level Cascaded H-Bridge Multilevel Inverter, IEEE International Conference on Advanced Communication Control and Computing Technologies, PP. 281-285.

[9] Hasan, M., Mekhilef, S., and Ahmed, M. 2014. ThreePhase Hybrid Multilevel Inverter With Less Power Electronic Components Using Space Vector Modulation, Institution of Engineering and Technology, Vol. 7, pp. 1256-1265.

[10] Urmila B., and Subbarayudu D. 2011. Harmonic Orientation Of Pulsewidthmodulation Technique Inmultilevel Inverters, Power Engineering And Electrical Engineering, VOL. 9, NO. 1, PP. 29-34.

[11] Prathiba, T., and Renuga. P. 2012. A Comparative Study of Total Harmonic Distortion in Multilevel Inverter Topology, Journal of Information Engineering and Applications, Vol.2, N0.3, PP.26-36. 